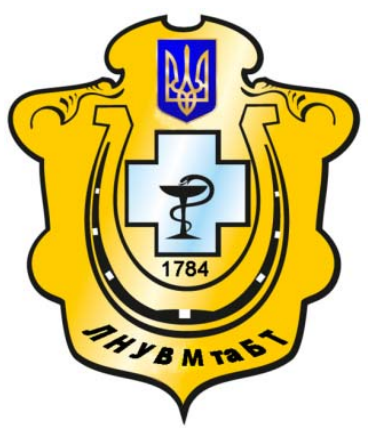

Науковий вісник Львівського національного університету ветеринарної медицини та біотехнологій імені С.3. Гжицького

Scientific Messenger of Lviv National University of Veterinary Medicine and Biotechnologies named after S.Z. Gzhytskyj

doi:10.15421/nvlvet7040

ISSN 2413-5550 print

ISSN 2518-1327 online

http://nvlvet.com.ua/

УДК 619 (477)

\title{
Ветеринарна медицина України і час реформ
}

\author{
Б.М. Куртяк ${ }^{1}$, М.С. Романович ${ }^{1}$, Т.О. Пундяк ${ }^{1}$, Л.В. Романович ${ }^{1}$, Р.В. Волошин ${ }^{2}$ \\ kurtakbohdan@gmail.com,r.m.s.@ukr.net; to-pundyak@i.ua, romanovichluda@gmail.com, \\ voloshyn@vetmed.lviv.ua
}

${ }^{1}$ Львівський наиіональний університет ветеринарної медицини та біотехнологій імені С.З. Гжицького, вул. Пекарська 50, м. Львів, 79010, Україна;

${ }^{2}$ Управління безпечності харчових продуктів та ветеринарії Головного управління Держпродспоживслужби у Львівській області, вул. Промислова, 9, м. Львів, 79000, Україна

Державна служба Украӥни з питань безпечності харчових продуктів та захисту споживачів (Держпродспоживслужба) є иеентральним органом виконавчої влади, реалізує держсвну політику у галузі ветеринарної медицини, сферах безпечності та окремих показників якості харчових продуктів, ідентифікаиії та реєстрачї тварин, санітарного законодавства, ринкового нагляду в межах сфери своєї відповідальності, державного контролю за додержанням законодавства про захист прав споживачів і рекламу в цій сфері згідно Закону України «Про основні принципи та вимоги до безпечності та якості харчових продуктів», який вступив в дію з 20 вересня 2015 року. Цим законом встановлюється принципово новий підхід до забезпечення безпечності харчових продуктів. Основна відповідальність за безпечність харчових продуктів покладається на виробників, а контроль держави спрямований не на готовий продукт, а на виробництво та обіг.

Єдиним контролюючим органом в сфері безпеки харчових продуктів в Україні, відповідно до Закону, є Державна служба з питань безпеки харчових продуктів та захисту споживачів. Служба здійснює свої повноваження безпосередньо та через територіальні органи - управління безпечності харчових продуктів та ветеринарії в областях, м.Києві, містах обласного підпорядкування, районах.

Внаслідок створення в Україні Держпродспоживслужби функціонує чітка вертикаль органів державного управління ветеринарної медицини, яку вимагає європейська спільнота, зокрема, ие структурно відповідає вимогам Свросоюзу. Основне їхнє завдання - багатогранність державного ветеринарного нагляду та його періодичність.

Ключові слова: Держпродспоживслужба, реформа, ветеринарна медичина, безпечність харчових продуктів, територіальні органи управління, протиепізоотичні заходи, лабораторія ветмедицини.

\section{Ветеринарная медицина Украины и время реформ}

\author{
Б.М. Куртяк ${ }^{1}$, М.С. Романович ${ }^{1}$, Т.А. Пундяк ${ }^{1}$, Л.В. Романович ${ }^{1}$, Р.В. Волошин ${ }^{2}$ \\ kurtakbohdan@gmail.com,r.m.s.@ukr.net; to-pundyak@i.ua, romanovichluda@gmail.com, \\ voloshyn@vetmed.lviv.ua
}

${ }^{1}$ Львовский нацииональный университет ветеринарной медицины и биотехнологий имени С.3. Гжицкого, ул. Пекарская, 50, г. Львов, 79010, Украина;

${ }^{2}$ Управления безопасности пищевых продуктов и ветеринарии Главного управления Держпродспоживслужбы во Львовской области, ул. Промьшиленная, 9, г. Львов, 79000, Украина

Государственная служба Украины по вопросам безопасности пищевых продуктов и защиты потребителей (Госпродспоживслужба) является центральным органом исполнительной власти, реализующии государственную политику в области ветеринарной медицины, сферах безопасности и отдельных показателей качества пищевых продуктов, идентификации и регистрации жсиотных, санитарного законодательства, рыночного надзора в пределах сферы своей ответственности, государственного контроля за соблюдением законодательства о защите прав потребителей и рекламе в этой сфере в

\section{Citation:}

Kurtyak, B.M., Romanovych, M.S., Pundyak, T.O., Romanovych, L.V., Voloshin, R.V. (2016). Veterinary medicine in Ukraine and time of reforms. Scientific Messenger LNUVMBT named after S.Z. Gzhytskyj, 18, 3(70), 171-173. 
соответствии с Законом Украины «Об основных приниипах и требования к безопасности и качеству пищевьх продуктов», который вступил в действие с 20 сентября 2015 года. Этим законом устанавливается принципиально новый подход к обеспечению безопасности пищевых продуктов. Основная ответственность за безопасность пищевых продуктов возлагается на производителей, а контроль государства направлен не на готовый продукт, а на производство и оборот.

Единственным контролируюшим органом в сфере безопасности пищевых продуктов в Украине, согласно закону, является Государственная служба по вопросам безопасности пищевых продуктов и защчтты потребителей. Служба осуществляет свои полномочия непосредственно и через территориальные органь - управления безопасности пищевых продуктов и ветеринарии в областях, Киеве, городах областного подчинения, районах.

Вследствие создания в Украине Госпродспоживслужбы функиионирует четкая вертикаль органов государственного управления ветеринарной медицины, которую требует европейское сообщество, в частности, это структурно соответствует требованиям Евросоюза. Основная их задача - многогранность государственного ветеринарного надзора и его периодичность.

Ключевые слова: Госпродспоживслужба, реформа, ветеринарная медицина, безопасность пищевьх продуктов, территориальные органы управления, противоэпизоотические мероприятия, лаборатория ветмедицины.

\title{
Veterinary medicine in Ukraine and time of reforms
}

\author{
B.M. Kurtyak ${ }^{1}$, M.S. Romanovych ${ }^{1}$, T.O.Pundyak ${ }^{1}$, L.V. Romanovych ${ }^{1}$, R.V. Voloshin ${ }^{2}$ \\ kurtakbohdan@gmail.com,r.m.s.@ukr.net; to-pundyak@i.ua, romanovichluda@gmail.com, \\ voloshyn@vetmed.lviv.ua \\ ${ }^{1}$ Lviv national university of veterinary medicine and biotechnologies named after S. Gzhytskyj, \\ Pekarska Str., 50, Lviv, 79010, Ukraine; \\ ${ }^{2}$ Office of Food Safety and Veterinary Derzhprodspozhyvsluzhby Main Department in Lviv region, \\ Industrial Str., 9, Lviv, 79000, Ukraine
}

The State Service of Ukraine on issues of food safety and consumer protection (Derzhprodspozhyvsluzhba) is a central executive body that implements the state policy in the field of veterinary medicine, the fields of security and individual food quality indicators, identification and registration of animals, sanitary legislation, market surveillance within the scope of their responsibilities, the state control over observance of legislation on consumer protection and advertising in this area in accordance with the law of Ukraine "on basic principles and requirements for safety and quality of food», which entered into force on 20 September 2015. This law establishes a new approach to food safety. The primary responsibility for food safety lies with the manufacturers, and government control is not directed to the finished product, and the production and trafficking.

The only supervisory body in the field of food safety in Ukraine, according to the law, is the State Service for Food Safety and Consumer Protection. Service exercises its powers directly and through its territorial bodies - food safety and veterinary control products in all areas of Kiev, and cities of regional subordination, areas.

As a result of the creation in Ukraine Derzhprodspozhyvsluzhby obtained a clear hierarchy of government veterinary medicine, required by the European Community, in particular, is structurally complies with the requirements of the European Union. Their main task - the diversity of the state veterinary supervision and its periodicity.

Key words: Derzhprodspozhyvsluzhba reform, veterinary medicine, food safety, territorial authorities, anti-epizootic measures, laboratory of veterinary medicine.

В Україні на даний час здійснюються інтенсивно реформи, які особливо стосуються адаптації нормативно - правової бази до вимог Європейського Союзу. В тому числі також активно відбуваються реформування у галузі ветеринарної медицини.

Так, згідно постанови КМУ від 10.09.2014року № 442 «Про оптимізацію системи центральних органів виконавчої влади» органом державного управління в галузі ветмедицини $є$ Державна служба України 3 питань безпечності харчових продуктів та захисту споживачів (Держпродспоживслужба).

Держпродспоживслужба $є$ центральним органом виконавчої влади, діяльність якого спрямовується i координується Кабінетом Міністрів України через Міністра аграрної політики та продовольства та який реалізує державну політику у галузі ветеринарної медицини, сферах безпечності та окремих показників якості харчових продуктів. Постановою КМУ від 02.09.2015 року № 667 затверджено положення про Держпродспоживслужбу. У положенні чітко визначено завдання та права Держпродспоживслужби України.
Структура Держпродспоживслужби України складається із:

- Департаменту безпечності харчових продуктів та ветеринарії;

- Департаменту фітосанітарної безпеки, контролю в сфері насінництва та розсадництва;

- Департаменту захисту споживачів;

- Управління, держнагляду за дотриманням санітарного законодавства.

Департаменти в свою чергу мають свої структурні відділи.

Держпродспоживслужбу очолює Голова, який призначається на посаду та звільняється 3 посади КМУ за поданням Прем'єр-міністра України, внесеним на підставі пропозицій Міністра аграрної політики та продовольства.

На сьогоднішній день Служба завершила всі необхідні заходи, пов'язані з державною реєстрацією, затвердженням положення, структури, штатного розпису апарату та кошторису.

На рівні областей, м.Києва, міст обласного підпорядкування, районів є створено територіальні органи 
управління центрального органу Держпродспоживслужби.

У областях створені Головні управління Держпродспоживслужби, до складу яких входять такі Управління: безпечності харчових продуктів та ветеринарії; фітосанітарної безпеки; контролю у сфері насінництва та розсадництва; державного нагляду за дотриманням санітарного законодавства.

На рівні обласних управлінь безпечності харчових продуктів та ветеринарії створено три відділи: державного контролю; організації протиепізоотичних заходів; безпечності харчових продуктів.

Аналогічна структура функціонує на рівні районів та міст обласного підпорядкування.

Структура центрального апарату та територіальні органи Держпродспоживслужби фінансуються централізовано з Держбюджету.

На рівні області діагностичну роботу здійснюють обласні регіональні лабораторії ветеринарної медицини, а в окремих областях районні лабораторії ветмедицини реорганізовані у міжрайонні, або переведені як структурні підрозділи обласних регіональних лабораторій ветеринарної медицини.

Основними виконавцями протиепізоотичних заходів, надання ветеринарних послуг тваринництву, здійснення інших функцій передбачених ветеринарним законодавством проводять районні та міські державні лікарні в структури яких входять дільничні лікарні, дільниці, пункти ветеринарної медицини. Державна мережа лікарень та лабораторій фінансується 3 місцевих бюджетів через Департаменти агропромислового розвитку обласних державних адміністрацій.

Державний нагляд і контроль щодо недопущення занесення $з$ територій інших держав, або карантинної зони, збудників особливо небезпечних хвороб - здійснюють Регіональні служби на кордоні і транспорті, які представлені такими службами: Донецькою, м. Донецьк; Львівською, м. Львів; Південною, м. Харків; Придніпровською, м. Дніпро; Одеською, м. Одеса.

Об'єкти державного ветеринарного нагляду (контролю) - забійні підприємства (забою тварин), м'ясорибо-молокопереробні підприємства можуть мати свою відомчу ветеринарну службу.
Як наслідок широкомасштабного впровадження реформ у галузі ветеринарної медицини постійно зростає сітка приватних структур - ветеринарні кабінети, клініки, лікарні, аптеки і ін..

\section{Висновки}

Складна епізоотична ситуація згідно даних МЕБу, як у світі так і в Україні (спалахи африканської чуми свиней, сказу), вимагають чіткої дієвої державної структури служби ветеринарної медицини та належного фінансування ऑiі діяльності, для своєчасного вирішення завдань, які покладаються на ветеринарну службу державою.

\section{Бібліографічні посилання}

Kodeks zdorov'ja nazemnyh tvaryn MEB, T 1. - Zagal'ni polozhennja. - Dev'jatnadcjate vydannja, 2014 (in Ukrainian).

Kodeks zdorov'ja nazemnyh tvaryn MEB, T 2. Rekomendacii' shhodo zahvorjuvan' Spysku MEB i inshyh vazhlyvyh dlja mizhnarodnoi' torgivli zahvorjuvan'. - Dev'jatnadcjate vydannja, 2014r. (in Ukrainian).

Zakon Ukrai'ny «Pro veterynarnu medycynu». - K., 2006, 100 (in Ukrainian).

Licenzijni umovy provedennja gospodars'koi' dijal'nosti z veterynarnoi' praktyky. - Nakaz Mi-nagropolityky Ukrai'ny vid 2.07.2001 r. №94/186 (in Ukrainian).

Polozhennja pro Derzhavnu sluzhbu Ukrai'ny z pytan' bezpechnosti harchovyh produktiv ta zahystu spozhyvachiv. Postanova Kabinetu Ministriv Ukrai'ny vid 02.09.2015r. №667 (in Ukrainian).

Postanova Kabinetu Ministriv Ukrai'ny vid 16.12.2015r. №1092 «Pro utvorennja terytorial'nyh organiv upravlinnja Derzhprodspozhyvsluzhby» (in Ukrainian).

Zakon Ukrai'ny «Pro osnovni pryncypy ta vy-mogy do bezpechnosti ta jakosti harchovyh produktiv», vid 20.09.2015 (in Ukrainian).

Стаття надійшла до редакичї 7.09.2016 